\title{
SYNTHESIS AND SPECTROSCOPIC STUDY OF SOME COORDINATIVE COMPOUNDS OF Co(III), Ni(II) AND Cu(II) WITH DIANILINE- AND DISULFANILAMIDEGLYOXIME
}

\author{
Andrei Rija*, Ion Bulhac, Eduard Coropceanu, Elena Gorincioi, Elena Calmîc, Alic Barbă, \\ Olga Bologa
}

Institute of Chemistry, Academy of Sciences of Moldova, 3 Academiei st., MD-2028, Chisinau, Moldova

E-mail: andreirija@yahoo.com, telfax (373) 22739611

\begin{abstract}
Directed synthesis of dianiline- $\left(\mathrm{DAnH}_{2}\right)$ and disulfanilamideglyoximes $\left(\mathrm{DSamH}_{2}\right)$ has been accomplished by condensation of dichloroglyoxime with aniline or sulfanilamide in 1:2 molar ratio, as well as their corresponding $\mathrm{Co}(\mathrm{III}), \mathrm{Ni}$ (II) and $\mathrm{Cu}$ (II) coordinative compounds. Composition, structure and some properties of dioximes and complexes have been established by using elemental analysis, UV-Vis, IR and NMR- spectroscopies. Dioxime coordination at the central atom and structure of complexes depends on $\mathrm{pH}$ of reaction medium: at $\mathrm{pH}=5-6$ - bisdioximates, whilst at $\mathrm{pH}=2$ - tris-dioximines are obtained. In the case of the corresponding tris-dioximines increment of the functional groups number in dioxime fragments, which can form intermolecular hydrogen bonds, leads to the augment of the stability of complexes.
\end{abstract}

Keywords: $\alpha$-dioximes, coordinative compounds, $3 \mathrm{~d}$ metals, spectroscopy.

\section{Introduction}

Actually vic-dioximates are appreciated as coordinative compounds possessing a broad spectrum of applications in branches as: analytical, biological, medicinal and pigment's chemistries. vic-Dioximes and the important role of their complexes, especially with 1.2-dioxime, have been widely investigated, while the substitution of some fragments of dioxime can significantly influence the structure and stability of complexes [1-4].

On interaction of amines or thiols with dichloroglyoxime or cianogen-di-N-oxide different symmetrically substituted derivatives of diamine- or dithioglyoxime have been obtained. New optically active vic-dioximes have been described and the syntheses of mono- and dinuclear complexes on their basis have been performed $[5,6]$.

Cobaloximes containing bis-(thiophenyl)glyoxime in equatorial plane have been studied [7]. It has been noted that the orientation of thiophenyl groups with respect to the dioximine plane varies depending on the size of axial ligand and influences the values of chemical shifts in NMR-spectra. The cis-position of thiodioxime from the equatorial plane reflects upon $\mathrm{Co}-\mathrm{C}$ bond reactivity in these complexes. A study with the use of cyclic voltametry has demonstrated that reduction $\mathrm{Co}(\mathrm{III}) / \mathrm{Co}(\mathrm{II})$ and $\mathrm{Co}(\mathrm{II}) / \mathrm{Co}(\mathrm{I})$ occurs easier in $\mathrm{ClCo}(\mathrm{dSPhgH})_{2} \mathrm{Py}(\mathrm{dSPhgH}$ - dithiophenylglyoxime) in comparison with other chlorocobaloximes (gH - glyoxime, dmgH -dimethylglyoxime, dpgH - diphenylglyoxime). Thus, the general investigations in this field clearly suggest that many of the axial ligand's chemical properties: spectroscopic, geometry, kinetics significantly depend on the changes in equatorial ligand.

Gumus et. al. [8] have shown that inclusion of hexilamine radical in dioxime fragment permits to obtain $\mathrm{Ni}(\mathrm{II})$ and $\operatorname{Pd}(\mathrm{II})$ dioximates and in their crystalline structure tubular channels with diameter $\sim 16 \AA$ were found.

Recent investigations have demonstrated the biostimulator activity of $\mathrm{Co}$ (III) dioximates upon fungi $[9,10]$. Supplementation the nutritive medium of these microorganisms with the mentioned compounds causes an enhancement of the outcome of enzime production and in some cases the technological cycle of cultivation the producer has been diminished [11].

On the basis of biostimulator effects in enzymogenesis processes of Co(III) complexes containing aniline or sulfanylamide on axial coordinate, their inclusion in dioximine moiety has been considered, aimed at obtaining the new dioximates of transition metals, which will accentuate these properties, as expected. Furthermore, the mobility of the „wings" of these dioximes can open interesting structural opportunities for obtaining the supramolecular systems. Preparation of dioximates with bulky ligands could make possible the formation of gaps in the crystalline structure [8], which is favourable for the intake of small molecules.

\section{Materials and methods}

Composition, structure and properties of oximes and complexes have been established on the basis of elemental analysis, as well as IR, UV-Vis and NMR spectroscopies data. IR-spectra of compounds were recorded at FT-IR Perkin Elmer Spectrometer 100 in vaseline oil at $4000-400 \mathrm{~cm}^{-1}$ and ATR at $4000-650 \mathrm{~cm}^{-1}$. UV-Vis spectra were recorded at Perkin Elmer Lambda 25 spectrophotometer in water solutions of compounds of $0.5 \cdot 10^{-4} \mathrm{~mol} / \mathrm{L}$. NMR-spectra were recorded on a Bruker spectrometer at $400.13 \mathrm{MHz}$ for ${ }^{1} \mathrm{H}$ and $100.61 \mathrm{MHz}$ for ${ }^{13} \mathrm{C}$ in DMSO-d ${ }_{6}$ using TMS as an internal reference. Chemical shifts $(\delta)$ are reported in parts per million (ppm) and are referenced to the residual non-deuterated solvent peak (2.49 for ${ }^{1} \mathrm{H}$ and 39.70 for $\left.{ }^{13} \mathrm{C}\right)$. 


\section{Experimental part}

Synthesis of coordinative reagents

Glyoxime has been synthesized according to the literature procedure [12] in $67 \%$ yield.

Dichloroglyoxime has been prepared as reported by Dutta et al. [7] in $\sim 35 \%$ overall yield. Compound is soluble in alcohols, DMF, DMSO.

Disulfanilamideglyoxime (DSamH $)_{2}$. The solution of $3.14 \mathrm{~g}(0.02 \mathrm{~mol})$ dichloroglyoxime in $15 \mathrm{ml}$ ethanol was added to a solution of $6.89 \mathrm{~g}(0.04 \mathrm{~mol})$ sulfanilamide in $40 \mathrm{ml}$ ethanol at room temperature (rt) under continuous stirring. The reaction mixture was cooled in ice bath for $10 \mathrm{~min}$, and then $3.20 \mathrm{~g}(0.03 \mathrm{~mol})$ sodium carbonate was added. The mixture was stirred for $6 \mathrm{hr}$, then diluted with $20 \mathrm{ml}$ water and left in refrigerator for the next day. The obtained precipitate was filtered off, washed with cold water and dried in air. Yield: 63\%. Found, \%: C 39.14; H 3.58; N 19.54. Calculated for $\mathrm{C}_{14} \mathrm{H}_{16} \mathrm{~N}_{6} \mathrm{O}_{6} \mathrm{~S}_{2}, \%$ : C 39.25; H 3.76; N 19.62 .

Dianilineglyoxime $\left(\mathbf{D A n H}_{2}\right)$ was prepared, in $93 \%$ yield, according to the procedure as described for preparation of disulfanilamideglyoxime. Found, \%: C 62.15; H 5.09; N 20.66. Calculated for $\mathrm{C}_{14} \mathrm{H}_{14} \mathrm{~N}_{4} \mathrm{O}_{2}, \quad \%$ : C 62.21; H 5.22; N 20.73

\section{Synthesis of coordinative compounds.}

$\left[\mathbf{N i}(\mathbf{D A n H})_{2}\right] \mathbf{C l}_{2} \cdot \mathbf{6} \mathbf{C H}_{3} \mathbf{O H}$ (1). To the warm solution of $0.27 \mathrm{~g}(1.0 \mathrm{mmol}) \mathrm{DAnH}_{2}$ in $30 \mathrm{ml}$ methanol the solution of $0.12 \mathrm{~g}(0.5 \mathrm{mmol}) \mathrm{NiCl}_{2} \cdot 6 \mathrm{H}_{2} \mathrm{O}$ in $20 \mathrm{ml}$ methanol was added. The obtained mixture was stirred for 5-10 min, then filtered and left at rt. After 2-3 days the crystals have appeared in solution of emerald color. The crystals are soluble in diethyl ether, alcohols, DMSO and DMF. The reaction yield constituted $46 \%$. Found, \%: C 50.78; H 5.81; N 14.76. Calculated for $\mathrm{C}_{48} \mathrm{H}_{66} \mathrm{Cl}_{2} \mathrm{~N}_{12} \mathrm{NiO}_{12}$ \% \%: C 50.90; $\mathrm{H}$ 5.87; N 14.84 .

[Ni(DAnH) $)_{2} \cdot \mathbf{H}_{2} \mathbf{O}$ (2). A solution of $0.27 \mathrm{~g}(1.0 \mathrm{mmol}) \mathrm{DAnH}_{2}$ in $30 \mathrm{ml}$ methanol was added to a solution of $0.12 \mathrm{~g}(0.5 \mathrm{mmol}) \mathrm{NiCl}_{2} \cdot 6 \mathrm{H}_{2} \mathrm{O}$ in $20 \mathrm{ml}$ methanol and the mixture was stirred for $10 \mathrm{~min}$ at $40-50^{\circ} \mathrm{C}$. Ammonia $(1-2$ drops, $25 \%$ ) was added while stirring. The color of solution changed from green to brown and a precipitate of the same color has been formed. The precipitate was filtered off, washed with cold methanol, ether and dried at rt. The reaction yield constituted 56\%. The complex is soluble in DMF and weakly soluble in methanol and DMSO. Found, \%: C 54.59; $\mathrm{H} 4.45 ; \mathrm{N}$ 18.09. Calculated for $\mathrm{C}_{28} \mathrm{H}_{28} \mathrm{~N}_{8} \mathrm{NiO}_{5}, \%$ : C 54.66; $\mathrm{H} 4.59 ; \mathrm{N} 18.21$.

$\left[\mathbf{C u}\left(\mathrm{DAnH}_{2}\right)_{3}\right] \mathbf{S O}_{4} \cdot 3 \mathrm{H}_{2} \mathbf{O}(\mathbf{3})$. For the synthesis of this complex similar conditions as for compound (1) were applied, but the solubilisation of $\mathrm{Cu}$ (II) salt in a minimal amount of water has preceded the addition of methanol. The reaction yield constituted $42 \%$. Compound is soluble in DMSO, DMF and alcohols. Found, \%: C 49.16; H 4.67; N 16.32. Calculated for $\mathrm{C}_{42} \mathrm{H}_{48} \mathrm{CuN}_{12} \mathrm{O}_{13} \mathrm{~S}, \%$ : $\mathrm{C} 49.24 ; \mathrm{H} 4.72 ; \mathrm{N} 16.41$.

$\left[\mathbf{C o}(\mathbf{D A n H})_{2}\left(\mathbf{T h i o}_{2}\right]_{2}\left[\mathbf{T i F}_{6}\right] \cdot 2 \mathrm{DMF} \cdot \mathbf{H}_{2} \mathbf{O}\right.$ (4). Dianilineglyoxime, $0.27 \mathrm{~g}(1.0 \mathrm{mmol})$ and thiocarbamide, $0.08 \mathrm{~g}$ $(1.0 \mathrm{mmol})$ were dissolved in a mixture of $10 \mathrm{ml} \mathrm{DMF}$ and $40 \mathrm{ml}$ methanol. The mixture was refluxed at $\sim 60^{\circ} \mathrm{C}$, under stirring. Chrystallohydrate $\mathrm{CoTiF}_{6} \cdot 6 \mathrm{H}_{2} \mathrm{O}, 0.17 \mathrm{~g}(0.5 \mathrm{mmol})$ was dissolved in $10 \mathrm{ml}$ water and added by dropping funnel $(\sim 1$ drop in $4-5 \mathrm{sec}$.) to the initial solution and stirring was continued for $3 \mathrm{hr}$. Ammonia solution (1:4) was dropped into reaction to adjust its $\mathrm{pH}$ to $\sim 5$ and this value was maintained till the end of reaction. The stirring was stopped and the reaction medium was left for slow evaporation. Dark brown monocrystalls were obtained that were unstable at air. Reaction yield constituted 19\%. Compound is soluble in DMF, DMSO and less soluble in alcohols. Found, \%: C 43.31; $\mathrm{H}$ 4.52; $\mathrm{N}$ 19.81. Calculated for $\mathrm{C}_{66} \mathrm{H}_{84} \mathrm{Co}_{2} \mathrm{~F}_{6} \mathrm{~N}_{26} \mathrm{O}_{11} \mathrm{~S}_{4} \mathrm{Ti}, \%$ : C 43.42; H 4.64; $\mathrm{N} 19.95$.

$\left[\mathbf{C o}\left(\mathbf{D A n H}_{2}\right)_{3}\right]_{2}\left[\mathrm{TiF}_{6}\right]_{3} \cdot \mathbf{1 . 5 D M F}(\mathbf{5})$. This compound has been synthesized as afore-described for (4), without the addition of ammonia solution. The results of investigations have shown that thiocarbamide moiety does not enter the complex and three molecules of non-deprotonated dioxime are bound to the central atom. Reaction yield constituted 32\%. Product is soluble in alcohols, DMF and DMSO. Found, \%: C 45.38; H 3.96; N 15.11. Calculated for $\mathrm{C}_{88.5} \mathrm{H}_{94.5} \mathrm{Co}_{2} \mathrm{~F}_{18} \mathrm{~N}_{25.5} \mathrm{O}_{13.5} \mathrm{Ti}_{3}, \%$ : C 45.53; H 4.08; N 15.30.

[Ni(DSamH) ${ }_{2} \cdot \cdot 2 \mathbf{H}_{2} \mathbf{O}(\mathbf{6})$. To the warm solution of $0.21 \mathrm{~g}(0.50 \mathrm{mmol})$ disulfanilamideglyoxime in $30 \mathrm{ml}$ methanol $0.06 \mathrm{~g}(0.25 \mathrm{mmol}) \mathrm{NiCl}_{2} \cdot 6 \mathrm{H}_{2} \mathrm{O}$ in $15 \mathrm{ml}$ methanol were added and the mixture was stirred for $15 \mathrm{~min}$ at $60^{\circ} \mathrm{C}$. While stirring few drops of ammonia was added and a brown precipitate appeared that was separated, washed with cold methanol then diethyl ether and dried at air. Reaction yield constituted $43 \%$. Complex is soluble in DMF and DMSO and weakly soluble in methanol. Found, \%: C 35.41; $\mathrm{H} 3.54 ; \mathrm{N} 17.62$. Calculated for $\mathrm{C}_{28} \mathrm{H}_{34} \mathrm{~N}_{12} \mathrm{NiO}_{14} \mathrm{~S}_{4}, \%$ : $\mathrm{C} 35.41 ; \mathrm{H}$ $3.61 ; \mathrm{N} 17.70$.

$\left[\mathbf{C u}\left(\mathrm{DSamH}_{2}\right)_{3}\right] \mathbf{S O}_{4} \cdot \mathbf{5 H}_{2} \mathbf{O}(\mathbf{7})$. Disulfanilamideglyoxime, $0.21 \mathrm{~g}(0.50 \mathrm{mmol})$ was dissolved in $40 \mathrm{ml}$ methanol and heated in water bath at $60^{\circ} \mathrm{C}$. Crystallohydrate $\mathrm{CuSO}_{4} \cdot 5 \mathrm{H}_{2} \mathrm{O}, 0.06 \mathrm{~g}(0.25 \mathrm{mmol})$ dissolved in a minimum amount of water and $20 \mathrm{ml}$ methanol was added dropwise to the solution of ligand, then heating was removed and the solution was left at rt. The slow evaporation gave dark-brown crystals. Reaction yield constituted $52 \%$. Compound is soluble in DMF and DMSO. Found, \%: C 32.72; H 3.71; N 16.34. Calculated for $\mathrm{C}_{42} \mathrm{H}_{58} \mathrm{CuN}_{18} \mathrm{O}_{27} \mathrm{~S}_{7}, \%$ : $\mathrm{C} 32.86 ; \mathrm{H} 3.81 ; \mathrm{N} 16.42$.

$\left[\mathbf{C o}(\mathbf{D S a m H})_{2}(\mathbf{T h i o})_{2}\right]_{2}\left[\mathrm{ZrF}_{6}\right] \cdot \mathbf{D M F} \cdot \mathrm{H}_{2} \mathrm{O}(\mathbf{8})$. A mixture of $0.21 \mathrm{~g}(0.5 \mathrm{mmol})$ disulfanilamideglyoxime in $30 \mathrm{ml}$ methanol and $0.04 \mathrm{~g}(0.5 \mathrm{mmol})$ thiocarbamide in $10 \mathrm{ml}$ methanol was refluxed at $60^{\circ} \mathrm{C}$ with stirring. To this mixture a solution of $0.1 \mathrm{~g}(0.25 \mathrm{mmol}) \mathrm{CoZrF}_{6} \cdot 6 \mathrm{H}_{2} \mathrm{O}$ in $20 \mathrm{ml}$ of water/methanol (1:1) was added. The reaction mixture was stirred for $3 \mathrm{hrs}$, while maintaining the $\mathrm{pH}$ of solution at 4.5-5.5 value by dropping ammonia solution (1:3). A 
dark brown precipitate was formed that was filtered off, washed with cold methanol and diethyl ether. Reaction yield constituted 36\%. Compound is soluble in methanol, DMF and DMSO. Found, \%: C 31.02; H 3.46; N 18.91. Calculated for $\mathrm{C}_{63} \mathrm{H}_{85} \mathrm{Co}_{2} \mathrm{~F}_{6} \mathrm{~N}_{33} \mathrm{O}_{26} \mathrm{~S}_{12} \mathrm{ZrS}, \%$ : C 31.16; H 3.53; N 19.03.

$\left[\mathbf{C o}(\mathrm{DSamH})_{2}(\mathrm{Thio})_{2}\right]_{2}\left[\mathrm{TiF}_{6}\right] \cdot \mathbf{1 . 5 D M F} \cdot \mathbf{2} \mathrm{H}_{2} \mathrm{O}(\mathbf{9})$. This compound was prepared according to the procedure as described for preparation of compound 8, by using $\mathrm{CoTiF}_{6} \cdot 6 \mathrm{H}_{2} \mathrm{O}$ instead of $\mathrm{Zr}$ crystallohydrate. Found, \%: C 31.64; $\mathrm{H}$ 3.61; N 19.08. Calculated for $\mathrm{C}_{64.5} \mathrm{H}_{90.5} \mathrm{Co}_{2} \mathrm{~F}_{6} \mathrm{~N}_{33.5} \mathrm{O}_{27.5} \mathrm{~S}_{12} \mathrm{Ti}, \%$ : C 31.75; H 3.74; N 19.23.

\section{Results and discussion}

As a result of the condensation between dichloroglyoxime and various organic amines, a series of $\alpha$-aminodioximes can be obtained, according to the following scheme:

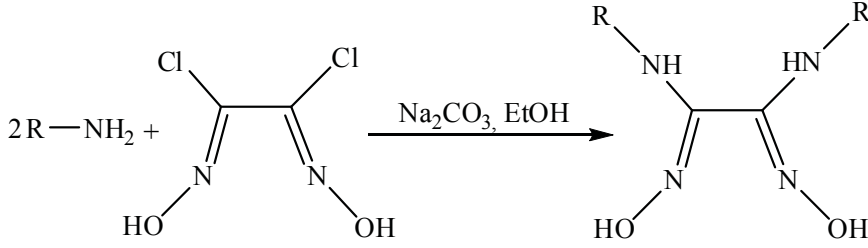

$\mathrm{R}-\mathrm{NH}_{2}$ - aniline or sulfanilamide

This approach served as basic for the obtaining of $\mathrm{DAnH}_{2}$ and $\mathrm{DSamH}_{2}$, the latter being synthesized for the first time. The prepared compounds were identified by elemental analysis, UV-Vis, IR and NMR spectroscopies. UVVis spectrum of $\mathrm{DAnH}_{2}$ contains two absorbtion bands at 205 and $260 \mathrm{~nm}$ belonging to the aromatic ring, whilst the corresponding UV-Vis spectrum of $\mathrm{DSamH}_{2}$ is characterized by the adsorption band at $281 \mathrm{~nm}$.

In the IR-spectrum of $\mathrm{DAnH}_{2}$ the following absorption bands are present: $v(\mathrm{OH})=3390, v(\mathrm{NH})=3369$, $v(\mathrm{C}=\mathrm{N})=1637, v(\mathrm{CC})_{\text {arom. }}=1596 \mathrm{~cm}^{-1}$. The $v(\mathrm{NO})=972 \mathrm{~cm}^{-1}$ band is characteristic for unprotonated oxime group, while $\delta(\mathrm{CH})_{\text {arom. }}=752$ and $689 \mathrm{~cm}^{-1}$ is attributed to monosubstituted aromatic ring. The presence of intensive bands: $v(\mathrm{NO})$ and $\delta(\mathrm{CH})$, as well as disappearance of $v(\mathrm{CCl})$ band at $850 \mathrm{~cm}^{-1}$ demonstrates that the condensation between dichloroglyoxime and aniline has occurred. In IR-spectrum of DSamH the absorption bands of $v(\mathrm{NH})=3424,3357,3283 \mathrm{~cm}^{-1}$ are present and $v(\mathrm{OH})=3076 \mathrm{~cm}^{-1}$ as well, which is shifted to lower values due to the formed by oxime $\mathrm{OH}$ molecular associates. The bands of $v(\mathrm{C}=\mathrm{N})=1642 \mathrm{~cm}^{-1}, v(\mathrm{CC})_{\text {arom }}=1592 \mathrm{~cm}^{-1}, v(\mathrm{SO})=1302,1150 \mathrm{~cm}^{-1}, v(\mathrm{NO})=935 \mathrm{~cm}^{-1}$ and $\delta(\mathrm{CH})=767,725$ $\mathrm{cm}^{-1}$ are also characteristic for this spectrum.

The ${ }^{1} \mathrm{H}$ NMR spectrum of $\mathrm{DAnH}_{2}$ contains the multiplets in $6.79-7.09 \mathrm{ppm}$ region that attest the presence of aromatic ring in compound, a singlet at $8.16 \mathrm{ppm}$ that is characteristic for the $\mathrm{NH}$ group proton and a singlet at 10.43 ppm confirming the presence of oxime group. Integration of the peaks in this spectrum has shown that both chlorine atoms of initial dichloroglyoxime were substituted by aniline radicals. The presence of 5 resonances in ${ }^{13} \mathrm{C}$ NMR spectrum, including quaternary atom of oxime group $\left(\delta_{\mathrm{C}}\right.$ 142.66), quaternary atom $\left(\delta_{C} 139.70\right)$ and tertiary atoms of aromatic ring $\left(\delta_{\mathrm{C}} 128.16,121.23\right.$ and 118.92) were ascribed to $\mathrm{DAnH}_{2}$.

The ${ }^{1} \mathrm{H}$ NMR spectrum of DSamH ${ }_{2}$ (Figure 1) contains two doublets belonging to the aromatic ring at $7.54 \mathrm{ppm}(2 \mathrm{H}, \mathrm{J}=8.78 \mathrm{~Hz})$ and $6.89 \mathrm{ppm}(2 \mathrm{H}, \mathrm{J}=8.78 \mathrm{~Hz})$, a singlet at $7.16 \mathrm{ppm}\left(\mathrm{NH}_{2}\right.$ protons $)$ and a singlet at $8.77 \mathrm{ppm}$ (NH proton). Oxime group protons give a peak at $10.89 \mathrm{ppm}$. In ${ }^{13} \mathrm{C}$ NMR spectrum the presence of tertiary

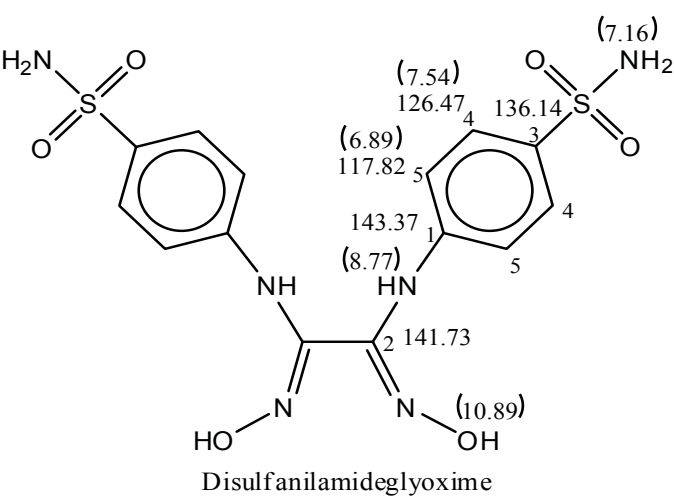

Fig. 1. Disulfanilamideglyoxime with its ${ }^{1} \mathrm{H}$ and ${ }^{13} \mathrm{C}$ values. carbon resonances $\left(\delta_{\mathrm{C}} 117.82\right.$ and 126.47$)$, quaternary atoms of aromatic ring $\left(\delta_{\mathrm{C}} 136.14\right.$ and 143.37) and oxime carbon atom $\left(\delta_{\mathrm{C}} 141.73\right)$ has been attested. It was found that protons and carbons signals appear downfield in disulfanilamideglyoxime, as compared to the sulfanilamide (Figure 2). Only quaternary carbon of aromatic ring close to $\mathrm{NH}$ group is upfield shifted by condensation. Both proton and carbon signals of oxime group are shifted to higher field as compared to the dichloroglyoxime. The attribution of the peaks for the carbon atoms has been performed on the basis of 2D NMR techniques: HSQC and HMBC (Figure 3). Also, in 2D $\mathrm{HMBC}$ experiment, the protons of $\mathrm{NH}$ and $\mathrm{OH}$ groups have a cross peaks at the shift of $\mathrm{C}^{2}$, that proves the condensation of sulfanilamide with dicloroglyoxime. As it can be concluded from these spectra, sulfanilamide condenses via amino group of aromatic ring: it suffers the biggest downfield shift and integration of the peaks confirms the loss of one proton from this group. 


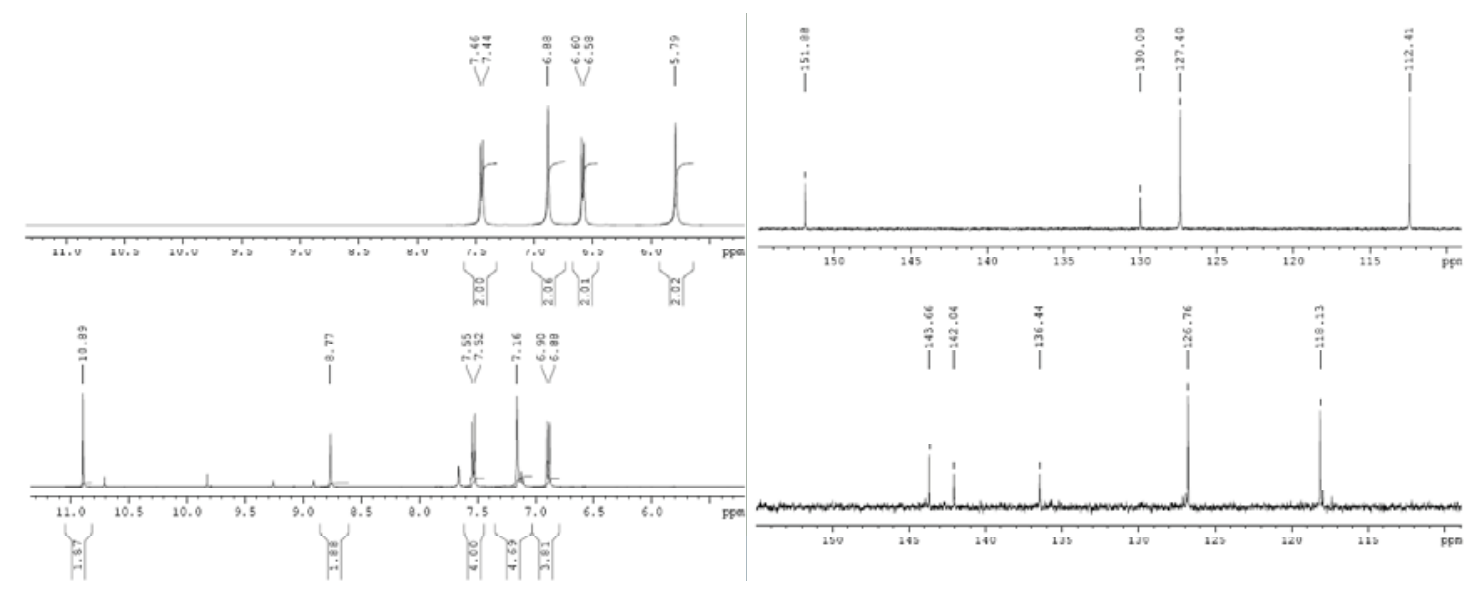

Fig. 2. ${ }^{1} \mathrm{H}$ and ${ }^{<} \mathrm{C}$ NMR spectra of sulfanilamide (a, b) and disuflanilamideglyoxime (c, d).

On interaction of a $\mathrm{Co}(\mathrm{II}), \mathrm{Ni}(\mathrm{II})$ or $\mathrm{Cu}(\mathrm{II})$ salt with the described dioximes in a 1:2 molar ratio, bis-dioximates or tris-dioximines of the corresponding metals were obtained, depending on the conditions of synthesis. The $\mathrm{pH} \sim 2$ is more favourable for the obtaining of tris-dioximines, while at $\mathrm{pH} \sim 5-6$ bis-dioximates of the respective metals are preferentially formed. Variation of the $\mathrm{pH}$ value was achieved by adding 1-2 drops of ammonia solution or hydrochloric acid. Methanol, water and dimethylformamide were used as solvents. A part of obtained complexes are unstable at air.

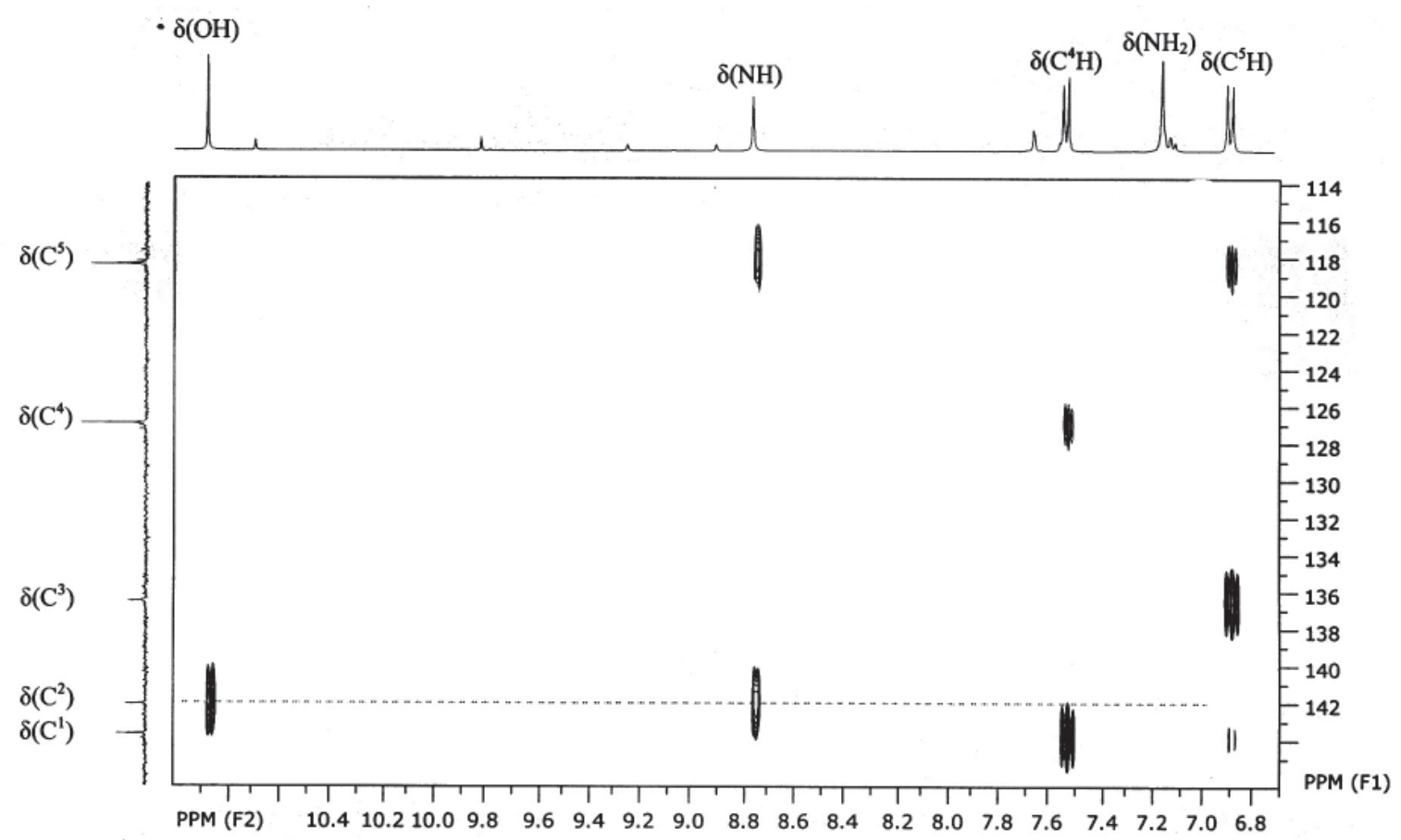

Fig. 3. 2D HMBC experiment of disulfanilamideglyoxime.

In UV-Vis spectra of $\mathrm{Ni}(\mathrm{II})$ and $\mathrm{Cu}(\mathrm{II})$ complexes containing $\mathrm{DAnH}_{2}$ characteristic bands of aromatic ring are noted at $\sim 205$ and $260 \mathrm{~nm}$, which certify the presence of this ligand in complex. In the case of bis-dianilineglyoximate of $\mathrm{Ni}(\mathrm{II})$ it has been observed that the corresponding absorption band at $260 \mathrm{~nm}$ is less intensive then the band at 205 $\mathrm{nm}$, as compared to tris-dianilineglyoximine. Furthermore, a new band appeared at $378 \mathrm{~nm}$ (Figure 4). The following explanation seems plausible: the composed band at $260 \mathrm{~nm}$ reflects two electronic transitions and the formation of trans-dioximates is accompanied by the disappearance of one transition as a result of an electron shift. In the case of complex $\left[\mathrm{Co}(\mathrm{DAnH})_{2} \mathrm{Thio}_{2}\left[\mathrm{TiF}_{6}\right]\right.$ three absorption bands were recorded: at $202 \mathrm{~nm}$, characteristic for aromatic ring; at $243 \mathrm{~nm}$ probably distinguishing $\pi-\pi^{*}$ transitions in chelate ring and a band at $321 \mathrm{~nm}$ that is attributed to the molecules of coordinated thiocarbamide. 


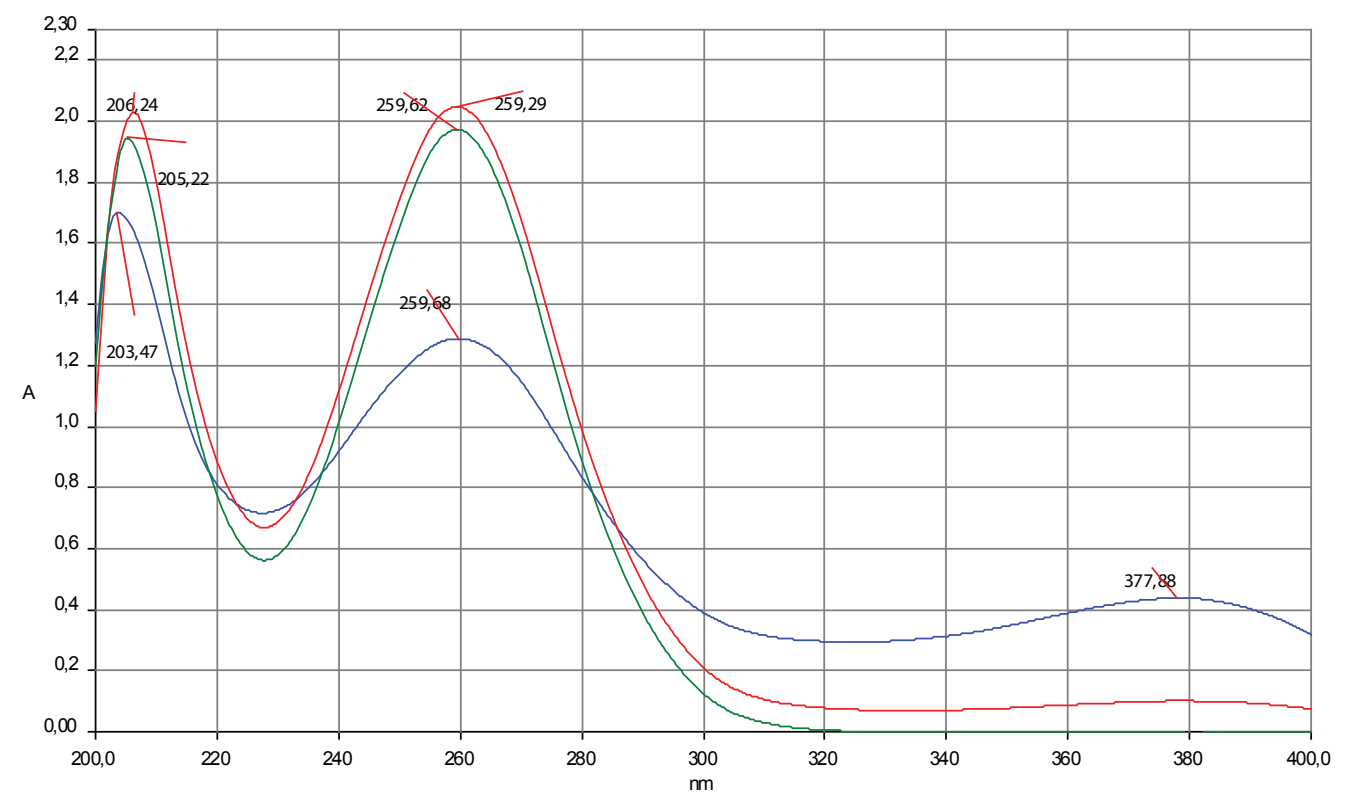

Fig. 4. UV-Vis spectra of compounds

$\mathrm{DAnH}_{2}(1),\left[\mathrm{Ni}\left(\mathrm{DAnH}_{2}\right)_{3}\right] \mathrm{Cl}_{2}(2),\left[\mathrm{Ni}(\mathrm{DAnH})_{2}\right]$ (3)

In the case of $\mathrm{Ni}(\mathrm{II})$ and $\mathrm{Co}(\mathrm{II})$ dioximates containing $\mathrm{DSamH}_{2}$ the presence of this ligand in the corresponding complexes has been certified by the absorption bands at 202 and 275-282 nm. Also in the case of these compounds it has been noted that the addition of one drop of ammonia, which favors the formation of bis-dioximates, causes the decrease in intensity of absorption band at $280 \mathrm{~nm}$. The generation of intramolecular hydrogen bonds contributes to the electron density shift from the aromatic ring towards metal-cycle, which could cause intensity diminution of the respective band.

In IR-spectra of $\mathrm{DAnH}_{2}$-containing tris-dioximines the absorption bands $v(\mathrm{NH})+v(\mathrm{OH})=3331-3380$, $v(\mathrm{C}=\mathrm{N})=1647-1655$ and $v(\mathrm{CC})_{\text {arom }}=1596 \mathrm{~cm}^{-1}$ are present. The presence of $v(\mathrm{NO})=970-998 \mathrm{~cm}^{-1}$ band, as well as the lack of characteristic ionized $v(\mathrm{NO})$ at $\sim 1240$ and $\sim 1080 \mathrm{~cm}^{-1}$ demonstrates the absence of $\mathrm{O}-\mathrm{H} \cdots \mathrm{O}$ intramolecular hydrogen bonds, proving the tris- character of these dioximines of $3 \mathrm{~d}$-metals. The absorption bands of vibrations $\delta(\mathrm{CH})$ that characterizes the aromatic monosubstituted ring are found at 752-755 and 691-695 $\mathrm{cm}^{-1}$ region. In bis-dioximates of $\mathrm{Co}(\mathrm{III}), \mathrm{Cu}(\mathrm{II})$ and $\mathrm{Ni}(\mathrm{II})$ with dianilineglyoxime the bands of valence vibrations $v(\mathrm{NH})+v(\mathrm{OH})=3209-3312 \mathrm{~cm}^{-1}$ are shifted to lower fields than in the free $\mathrm{DAnH}_{2}$ molecule. The bands $v(\mathrm{C}=\mathrm{N})$ at $1647-1652$ and $v(\mathrm{CC})_{\text {arom }}$ at $1592-1594 \mathrm{~cm}^{-1}$ regions are present. Decrease in intensity of $972 \mathrm{~cm}^{-1}$ band, as well as appearance of the bands belonging to the ionized $\mathrm{N}-\mathrm{OH}$ group at $1234-1241 \mathrm{~cm}^{-1}$ and $1075-1093 \mathrm{~cm}^{-1}$ regions implies the formation of $\mathrm{O}-\mathrm{H} \cdots \mathrm{O}$ intramolecular hydrogen bonds. Bands $\delta(\mathrm{CH})$ are present at 747-753 and $689-694 \mathrm{~cm}^{-1}$ regions, characterizing the aromatic monosubstituted ring.

In IR-spectra of tris-dioximines containing $\mathrm{DSamH}_{2}$ the bands $v(\mathrm{NH})=3469-3208, v(\mathrm{OH})=3071-3075$, $v(\mathrm{C}=\mathrm{N})=1643-1646, v(\mathrm{C}-\mathrm{C})_{\text {arom }}=1588-1595, v(\mathrm{NO})=900-913$ and $\delta(\mathrm{CH})=741-747 \mathrm{~cm}^{-1}$ are found. In IR-spectra of bisdisulfanilamideglyoximates of $\mathrm{Co}$ (III) and $\mathrm{Ni}(\mathrm{II})$, as in the similar complexes with $\mathrm{DAnH}_{2}$, the majority of the aforementioned bands are present. Decrease in intensity of the band from $935 \mathrm{~cm}^{-1}$ region has been established and the bands of oxime $\mathrm{N}-\mathrm{OH}$ ionized group at 1255-1258 and $1093-1096 \mathrm{~cm}^{-1}$ appeared, which prove the formation of $\mathrm{O}-\mathrm{H} \cdots \mathrm{O}$ intramolecular hydrogen bonds.

In the case of $\mathrm{Co}(\mathrm{III})$ dioximates containing on axial coordinate the molecules of thiocarbamide the presence of ligand in complex is ascertained by the pronounced band $v(\mathrm{C}=\mathrm{S})=1396-1408 \mathrm{~cm}^{-1}$.

In ${ }^{1} \mathrm{H}$ NMR spectrum of complex $\left[\mathrm{Co}\left(\mathrm{DAnH}_{2}\right)_{3}\right]_{2}\left[\mathrm{TiF}_{6}\right]_{3} \cdot 4 \mathrm{DMF}$ the peak of oxime proton is more shielded $(9.10$ ppm), as compared with the free ligand peak at $10.43 \mathrm{ppm}$. The peak of NH group does not suffer any chemical shift with respect to the case of free ligand, being found at $8.15 \mathrm{ppm}$. The peaks of aromatic ring of $\mathrm{DAnH}_{2}$, a doublet and two triplets are found in 6.70-7.16 ppm region, as in the spectrum of free ligand. The only upfield chemical shift of the oxime proton peak is probably caused by an electronic density migration from metal to chelate ring. The peaks at 2.73 and $2.89 \mathrm{ppm}$ characterize the methyl groups and at $7.95 \mathrm{ppm}$ the methine group of dimethylformamide molecules from complex.

In ${ }^{13} \mathrm{C}$ NMR spectrum of this complex the peak of oxime carbon atom is upfield too, being found at $142.37 \mathrm{ppm}$, thus confirming the supposition on an electronic density migration from metal to chelate ring. The chemical shifts of aromatic carbon atoms at 118-140 ppm do not essentially vary from the corresponding values in the spectrum of the free 
ligand. Despite the introduction of the Thio ligand in the reaction medium, neither IR nor NMR spectra could certify its presence. The upfield shift of the oxime proton peak, as well as integration of the peaks in ${ }^{1} \mathrm{H}$ NMR spectrum, rule out the supposition on deprotonation of oxime group, thus constituting a further evidence (along with the elemental analysis, UV-Vis and IR-data) about Co(III) tris-dianilineglyoximine formation. The tris-dioximines of Ni(II) and Cu(II) were also obtained when the reactions were performed in the absence of ammonia or sodium acetate, according to the IR, UV-Vis and elemental analysis data. When an ammonia solution is added to the reaction medium, the formation of respective bis-dioximates occurred that has been ascertained by the chemical shift of oxime proton at $\sim 17-18 \mathrm{ppm}$ in ${ }^{1} \mathrm{H}$ NMR spectrum, proving the intramolecular hydrogen bond formation.

In the case of ${ }^{1} \mathrm{H}$ NMR spectrum of $\mathrm{Co}(\mathrm{III})$ tris-disulfanilamideglyoximine the oxime proton peak is also upfield with $\sim 1 \mathrm{ppm}$ (from $10.89 \mathrm{ppm}$ in the free ligand to 9.79-9.69 ppm). The chemical shift assigned to NH group is slightly upfield (8.36-8.25 ppm) with respect to the peak of free oxime at $8.76 \mathrm{ppm}$. These upfield shifts are attributed to an electron density migration from metal to the chelate ring, similarly to the afore-mentioned case of tris-form of dianilineglyoxime complexes. The two doublets assigned to the aromatic ring protons at 7.64 and $6.81 \mathrm{ppm}$ are placed approximately in the same region, as compared with the free disulfanilamideglyoxime. The peak of $\mathrm{NH}_{2}$ group does not essentially move in the spectrum, being found at $7.16 \mathrm{ppm}$, as well.

Considering the ${ }^{1} \mathrm{H}$ NMR spectrum of $\left[\mathrm{Ni}(\mathrm{DSamH})_{2}\right] \cdot 2 \mathrm{H}_{2} \mathrm{O}$ complex, the peak of oxime proton is downfield at $17.32 \mathrm{ppm}$, which confirms the intramolecular hydrogen bond formation between dioxime monoanions. The proton peaks of $\mathrm{NH}(9.84 \mathrm{ppm})$ and vicinal to it $\mathrm{CH}(7.84 \mathrm{ppm})$ groups are also downfield, being shifted with $\sim 1 \mathrm{ppm}$, as compared with the free ligand (8.77 and $6.89 \mathrm{ppm}$, respectively). The other peaks ( $\mathrm{CH}$ remote from oxime group at $7.69 \mathrm{ppm}$ and $\mathrm{NH}_{2}$ at $7.27 \mathrm{ppm}$ ) do not markedly differentiate as compared with the free ligand. In ${ }^{13} \mathrm{C} \mathrm{NMR}$ spectrum the most downfield chemical shift belongs to the peak of the quaternary oxime carbon at $146.11 \mathrm{ppm}(141.73 \mathrm{ppm}$ in the free ligand). Since ${ }^{1} \mathrm{H}$ NMR operates in a through-bond as well as through-space manner but ${ }^{13} \mathrm{C}$ NMR operates mainly through-bond, any shift in ${ }^{13} \mathrm{C} \delta(\mathrm{C}=\mathrm{N})$ will be due to cobalt anisotropy or Sam fragment (if is considered as an acceptor group of electron density). The peaks of quaternary carbon atom and methine close to $\mathrm{SO}_{2}$ group are slightly downfield with 1.0-1.2 ppm, the corresponding nuclei resonating at 136.81 and $127.39 \mathrm{ppm}$. The chemical shift of the other methine group is upfield, as compared with the free ligand (116.57 ppm versus $117.82 \mathrm{ppm}$, respectively).

${ }^{1} \mathrm{H}$ and ${ }^{13} \mathrm{C}$ NMR spectra of the other synthesized bis-disulfanilamideglyoximates do not essentially differ from the spectra of $\left[\mathrm{Ni}(\mathrm{DSamH})_{2}\right] \cdot 2 \mathrm{H}_{2} \mathrm{O}$ complex.

To summarize, $\mathrm{DAnH}_{2}$ and $\mathrm{DSamH}_{2}$ behave differently from the dimethylglyoxime, diphenylglyoxime or 1.2-cilcohexandiondioxime. In reaction with $\mathrm{Co}(\mathrm{II}), \mathrm{Ni}(\mathrm{II})$ and $\mathrm{Cu}(\mathrm{II})$ salt, $\mathrm{DAnH}_{2}$ and $\mathrm{DSamH}_{2}$ are prone to form tris-dioximines and not bis-dioximates like traditional dioximes. The tris-dioximine complexes with $\mathrm{DSamH}_{2}$ are $\mathrm{most}$ stable than those with $\mathrm{DAnH}_{2}$ due to a larger number of functional group that can participate to a hydrogen bond linkage. The new complexes may be effective as stimulators in biosynthetic processes of enzymes in some fungi strains.

\section{References}

[1]. Underhill, A. E.; Watkins, D. M. and Petring R., Inorg. Nucl. Chem.Lett., 9, 1269, (1973).

[2]. İrez, G. and Bekaroğlu, Ö. Synth. React. Inorg. M., 13, 781, (1983).

[3]. Serin, S. and Bekaroğlu, Ö. Z. Anorg. Allg. Chem., 496, 197, (1983).

[4]. Gök, Y. and Serin, S., Synth. React. Inorg. M., 18, 975, (1988).

[5]. Koçak, M., Bekaroglu, Ö. J. Coord. Chem., 47, Issue 2, 359, (1999).

[6]. Gürsoy, S. et. al. Transition Metal Chemistry, 25, 474, (2000).

[7]. Dutta, G.; Kumar K. and Gupta, B. D.. Organometallics, 28, 3485, (2009).

[8]. Gulay Gumus, et. al., New J. Chem., 28, 177, 2004.

[9]. Десятник А.А., и. др. Коорд. химия. Т.28, №2, 144, 2002.

[10]. Coropceanu, E. ş.a. Bul. Instit. Politehnic din Iaşi. T. XLIX (LIII). Fasc. 5, 293, (2003).

[11]. Deseatnic, A., ş.a., 2009.07.31, BOPI nr. 7/2009.

[12]. http://www.sciencemadness.org/member_publications/energetic glyoxime and diaminofurazan_derivatives. pdf 